\title{
Development of Grb2 SH2 Domain Signaling Antagonists: A Potential New Class of Antiproliferative Agents
}

\author{
Terrence R. Burke $\mathbf{J r}^{1,2}$
}

\author{
(Received August 22, 2005)
}

\begin{abstract}
Aberrant signaling through protein-tyrosine kinase (PTK)-dependent pathways is associated with several proliferative diseases. Accordingly, PTK inhibitors are being developed as new approaches for the treatment of certain cancers. Growth factor receptor bound protein 2 (Grb2) is an important downstream mediator of PTK signaling that serves obligatory roles in many pathogenic processes. One of the primary functions of Grb2 is to bind to specific phosphotyrosyl (pTyr)-containing sequences through its Src homology 2 (SH2) domain. Agents that bind to the Grb2 SH2 domain and prevent its normal function could disrupt associated PTK signaling and serve as alternatives to kinase-directed inhibitors. Starting from the X-ray crystal structure of a lead peptide bound to the Grb2 SH2 domain, this review will summarize important contributions to these efforts. The presentation will be thematically arranged according to the region of peptide modified, proceeding from the $\mathrm{N}$-terminus to the C-terminus, with a special section devoted to aspects of conformational constraint.
\end{abstract}

KEY WORDS: Grb2; peptide mimetic; phosphotyrosyl; SH2 domain; signaling inhibitor.

\section{INTRODUCTION}

Proliferative diseases often involve aberrations in protein-tyrosine kinase (PTK) dependent signaling (Blume-Jensen and Hunter, 2001), and for this reason PTK inhibitors are beginning to emerge as a new class of anticancer therapeutics (Shawver et al., 2002). However, blockade of oncogenic PTK signaling can be approached by means other than kinasedirected agents. Illustrative of this, the growth factor receptor bound protein 2 (Grb2) (Lowenstein et al., $1992)$ is a $25 \mathrm{kDa}$ non-catalytic Src homology 2

${ }^{1}$ Laboratory of Medicinal Chemistry, Center for Cancer Research, National Cancer Institute, National Institutes of Health, NCIFrederick, Frederick, MD, USA.

${ }^{2}$ Correspondence should be addressed to: Terrence R. Burke Jr, Laboratory of Medicinal Chemistry, Center for Cancer Research, National Cancer Institute, National Institutes of Health, NCIFrederick, Bldg. 376 Boyles St., P.O. Box B, Frederick, MDd, 21702-1201, USA. Tel.: (301) 846-5906; Fax: (301) 846-6033; E-mail: tburke@helix.nih.gov.
(SH2) domain-containing protein providing connectivity downstream of PTKs that has been shown to be associated with a number of cancers (Million and Van Etten, 2000; Tari and Lopez-Berestein, 2001; Saucier et al., 2002), including breast cancer (Daly et al., 1994). Significant effort has been devoted to developing Grb2 SH2 domain-binding antagonists as potential therapeutics. Because the recognition and binding to phosphotyrosyl (pTyr) containing sequences by the Grb2 SH2 domain is critical for its proper function, most inhibitor development has focused on peptide and peptide mimetic-based analogues (Fretz et al., 2000; Vu, 2000; GarciaEcheverria, 2001). Starting from the X-ray crystal structure of a lead peptide bound to the Grb2 SH2 domain, this review will summarize important

Abbreviations: EGFR, epidermal growth factor receptor; Grb2, growth factor receptor bound protein 2; HGF, hepatocyte growth factor; pTyr, phosphotyrosyl; PTK, protein-tyrosine kinase; RCM, ring closing metathesis; SH2, Src homology 2. 
contributions to these latter efforts. The reader is referred to an earlier review for a particularly fine presentation of work through the year 2000 (Fretz et al., 2000).

\section{RELATIONSHIP OF GRB2 SH2 DOMAIN- BINDING INTERACTIONS TO INHIBITOR DESIGN}

SH2 domains comprise a family of proteins characterized by similar overall structures that can be described using a common nomenclature. This allows a systematic designation of individual protein residues based on consensus motifs (Eck et al., 1993; Waksman et al., 1993). Shared topographical features among $\mathrm{SH} 2$ domains include three principal antiparallel $\beta$-sheets ( $\beta \mathrm{B}-\beta \mathrm{D})$ lying between C-proximal $(\alpha \mathrm{A})$ and $\mathrm{N}$-proximal $(\alpha \mathrm{B}) \alpha$-helixes, with shorter $\beta$-sheets $(\beta \mathrm{E}$ and $\beta \mathrm{F})$ and several short loops (BC, EF and BG) connecting these elements (Songyang, 1999). The binding of pTyr-containing peptides to $\mathrm{SH} 2$ domains typically involves nestling of the critical pTyr residue into a positively-charged pocket lying under the $\alpha \mathrm{A}$ helix next to the $\mathrm{BC}$ loop. Ligand residues C-proximal to the pTyr residue provide for differential affinity among various $\mathrm{SH} 2$ domain family members by extending in linear fashion through a 'specificity' region of the protein bounded by the EF and BG loops. The consensus sequence for peptides binding to the Grb2 SH2 is pTyr- $(\mathrm{X}+1)$ Asn- $(\mathrm{X}+3)$, (where residue numbering starts at the pTyr residue and proceeds in the C-terminal direction) with the $\mathrm{pTyr}+2$ Asn serving as the specificity determining residue (Songyang et al., 1994; Kessels et al., 2002). X-ray crystal structures of peptides complexed to Grb2 SH2 domains have shown that ligand cannot extend in the normal fashion between the $\mathrm{EF}$ and $\mathrm{BG}$ loops, because this region is blocked by the indole side chain of Trp EF1 (Rahuel et al., 1996, 1998; Ettmayer et al., 1999; Furet et al., 1999; Schiering et al., 2000; Nioche et al., 2002). This blockade results in the preferential binding of peptides to Grb2 SH2 domains in type-I $\beta$-turn conformations (Rahuel et al., 1996).

Figure 1 summarizes important Grb2 $\mathrm{SH} 2$ domain-binding interactions of the BCR-Abl $1_{174-180}$ peptide Lys-Pro-Phe-pTyr-Val-Asn-Val, including its adaption of a $\beta$-turn conformation (Rahuel et al., 1996). Since it had been observed that the N-terminal Lys and Pro residues do not exhibit specific interactions with the protein, these were omitted from the

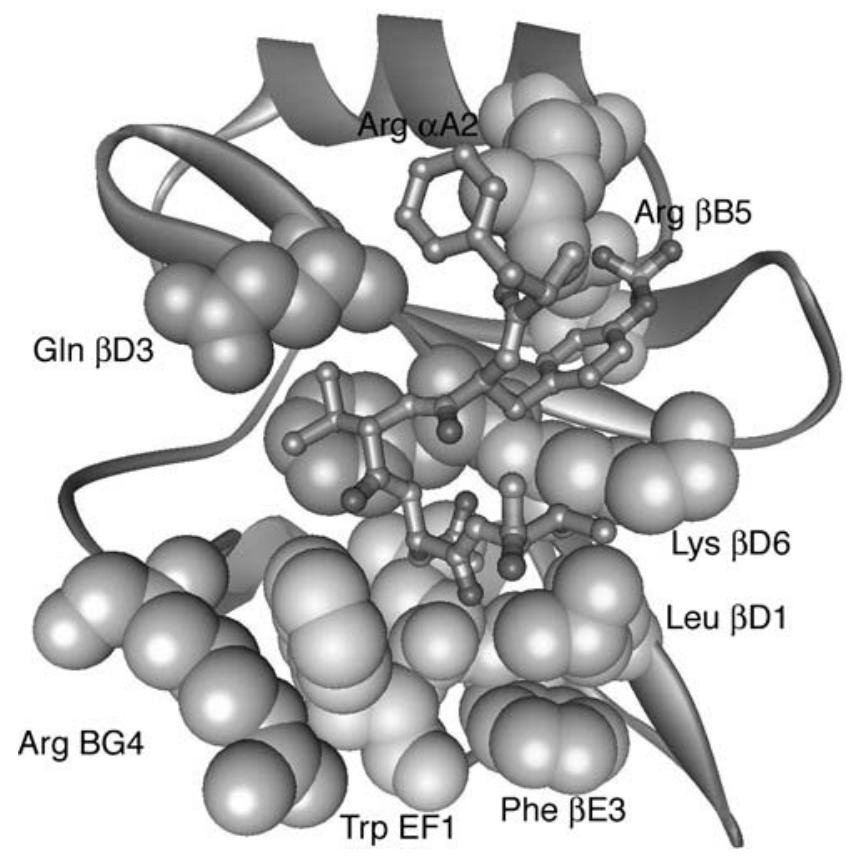

Fig. 1. X-ray crystal structure of the BCR-Abl ${ }_{174-180}$ sequence KPFpYVNV complexed to the Grb2 SH2 domain as reported in (Rahuel et al., 1996) with N-terminal Lys and Pro residues having been omitted for clarity. Important protein residues discussed in the text have been rendered in CPK style and labeled. 
Figure. However the carbonyl oxygen and phenyl ring of the pTyr-1 Phe residue do engage in hydrogen bonding and van der Waals interactions, respectively, with the $\operatorname{Arg} \alpha \mathrm{A} 2$ guanidinium group and these were retained in the Figure. The critical pTyr phosphoryl group forms hydrogen bonds with the $\operatorname{Arg} \alpha \mathrm{A} 2$ and Arg $\beta$ B5 side chains, while the pTyr phenyl ring undergoes hydrophobic interactions with side chain methylenes of Lys $\beta$ D6 in addition to $\pi$-cation interactions with the $\operatorname{Arg} \alpha \mathrm{A} 2$ guanidinium group. The $\mathrm{pTyr}+1$ Val residue exhibits hydrophobic interactions with the Phe $\beta \mathrm{D} 5$ and Gln $\beta$ D3 side chains, while the carboxamido side chain group of the critical $\mathrm{pTyr}+2$ Asn residue forms three hydrogen bonds with the Lys $\beta$ D6 and Leu $\beta$ E4 residues in the 'specificity determining pocket.' Finally, the pTyr +3 Val residue rests on a hydrophobic patch formed by the side chains of the Lys $\beta$ D6 and Leu $\beta$ D1 and bounded by Phe $\beta \mathrm{E} 3$. In the remainder of this review each of the above regional interactions will be used as the basis for summarizing studies directed toward the development of Grb2 SH2 domain-binding antagonists.

\section{AMINO-TERMINAL MODIFICATIONS}

Amino-terminal modifications have most often been directed at enhancing interactions with the Arg $\alpha \mathrm{A} 2$ guanidinium group. Furet et al. found that an approximate 7 -fold increase in binding affinity resulted relative to H-pTyr-Ile-Asn-amide (1a), by introducing an $\mathrm{N}$-terminal carboxamido moiety provided either by an acetyl group (1b) or by a Glu residue (1c) (Fig. 2) (Furet et al., 1997). Surprisingly, acylation of the Glu residue with a 2-aminobenzoyl group (Abz) increased affinity more than 300-fold (peptide 1d). X-ray crystallographic structure determination of 1d complexed to the Grb2 SH2 domain showed that the 2-amino group formed a salt bridge with the pTyr phosphoryl group, thereby positioning the Abz phenyl ring for efficient $\pi$-cation stacking with the Arg $\alpha \mathrm{A} 2$ guanidinium group (Rahuel et al., 1998). A similar, though slightly less potent effect could be achieved by acylating the pTyr residue directly with a 3-aminobenzyloxycarbonyl ((3-amino)Z) group (peptide 1e). The importance of amino functionality for maintaining a salt bridge with the<smiles>[Y]NC(Cc1ccc(OP(=O)(O)O)cc1)C(=O)N[C@H](C(=O)N[C@H](CC(N)=O)C(N)=O)C(C)C(C)C(C)C</smiles>

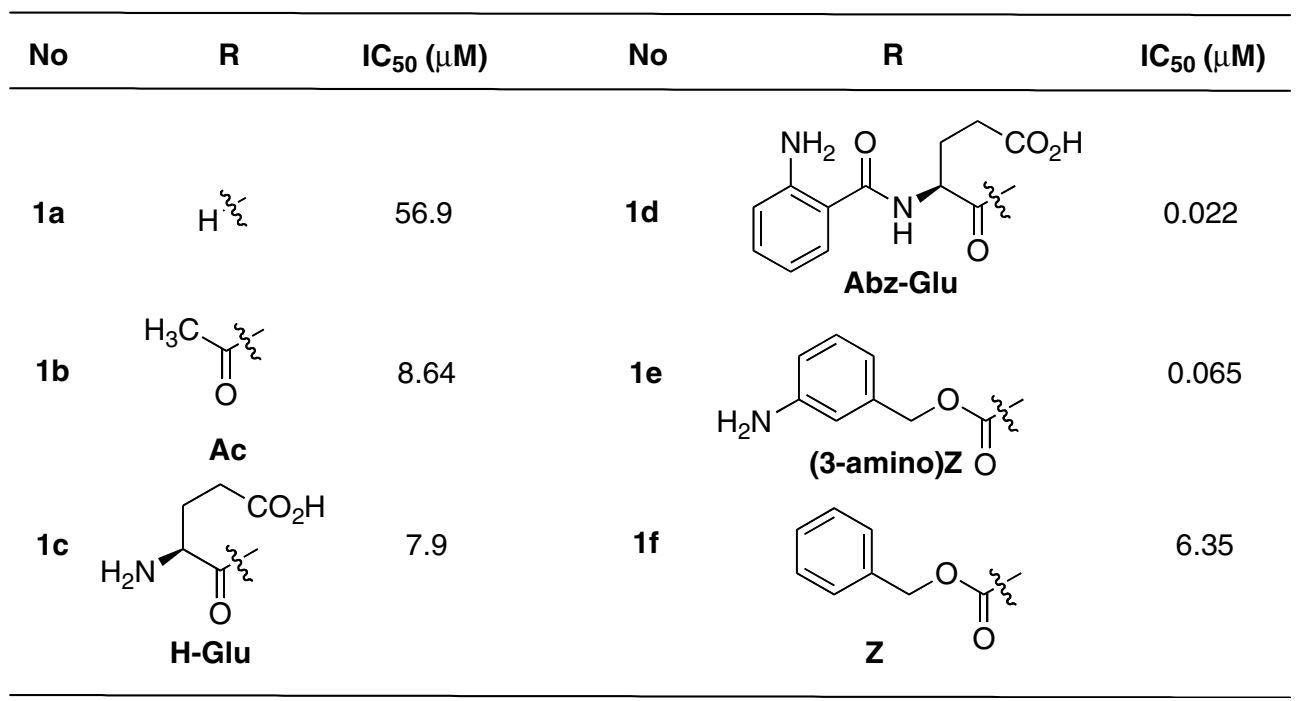

Fig. 2. Amino-terminal modifications reported in (Furet et al., 1997). 


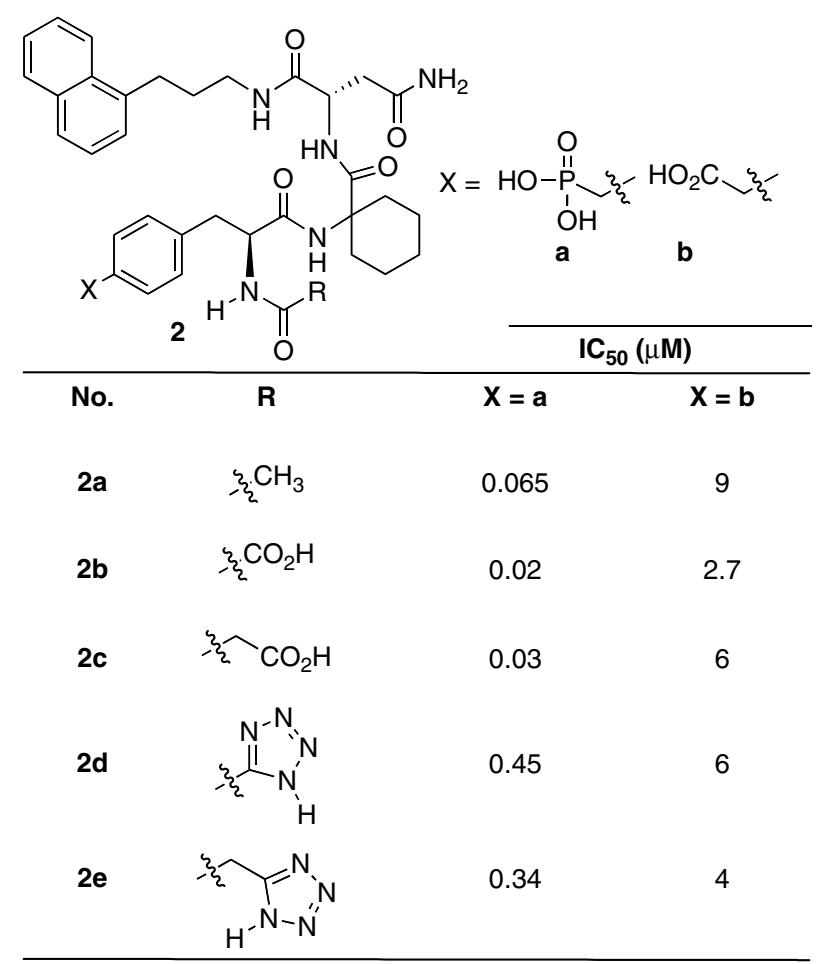

Fig. 3. Amino-terminal modifications presented in (Burke et al., 2001a).

phosphoryl group was shown by the nearly 100 -fold loss of affinity following removal of the 3 -amino group (peptide 1f).

Using as a display platform, a tripeptide disclosed by Furet et al. (2, Fig. 3) (Furet et al., 1998), Burke et al. examined a series of $\mathrm{N}$-terminal amides containing carboxyl and tetrazolyl groups intended to undergo ionic interactions with the $\operatorname{Arg} \alpha \mathrm{A} 2$ guanidinium group (peptides 2a-2e, Fig. 3) (Burke et al., 2001a). The N-oxalyl moiety (2b) provided the best affinity enhancement. Although affinity was only approximately 3 -fold greater than the N-Acetyl containing analogue (2a) in extracellular binding assays, potency in whole cells was increased in spite of the fact that the $\mathrm{N}$-oxalyl group would have been expected to adversely affect cellular bioavailability (Yao et al., 1999).

\section{pTyr MIMETICS}

Interactions within the $\mathrm{SH} 2$ domain $\mathrm{pTyr}$-binding pocket are central to overall ligand affinity, with ionic bonding between the phosphoryl group and the Arg $\beta$ B5 residue being particularly important (Bradshaw et al., 1999). However, the pTyr phosphoryl group (3a,
Fig. 4) presents physiochemical properties that are unsuitable for therapeutically-relevant $\mathrm{SH} 2$ domainbinding antagonists. These properties include poor bioavailability due to the di-anionic nature of the phosphoryl group at $\mathrm{pH} 7$ and hydrolytic lability of the phosphoryl ester to phosphatases. Accordingly, significant effort has been devoted to developing pTyr mimetics that address these drawbacks while retaining recognition within the pTyr-binding pocket (Burke et al., 2001b; Burke and Lee, 2003). Among the di-acidic pTyr mimetics that have been successfully used in high affinity Grb2 SH2 domain-binding antagonists are phosphorus-containing (phosphonomethyl)phenylalanine (Pmp, 3b) and (difluorophosphonomethyl)phenylalanine $\left(\mathrm{F}_{2} \mathrm{Pmp}, \quad 3 \mathrm{c}\right)$ (Yao et al., 1999). Non-phosphorus-containing analogues include the malonyl-containing $O$-malonyltyrosine (OMT, 3d) (Ye et al., 1995), $O$-fluoromalonyltyrosine (FOMT, 3e) and $p$-malonylphenylalanine (3f) (Gao et al., 2000). Modification of OMT by translocation of one carboxyl from the malonyl group to the 3-position of the tyrosyl ring provided analogue $\mathbf{3 g}$ (Yao et al., 1999).

The pTyr mimetics shown in Fig. 4 retain the di-acidic character of the parent phosphoryl-containing species and therefore potentially present membrane 


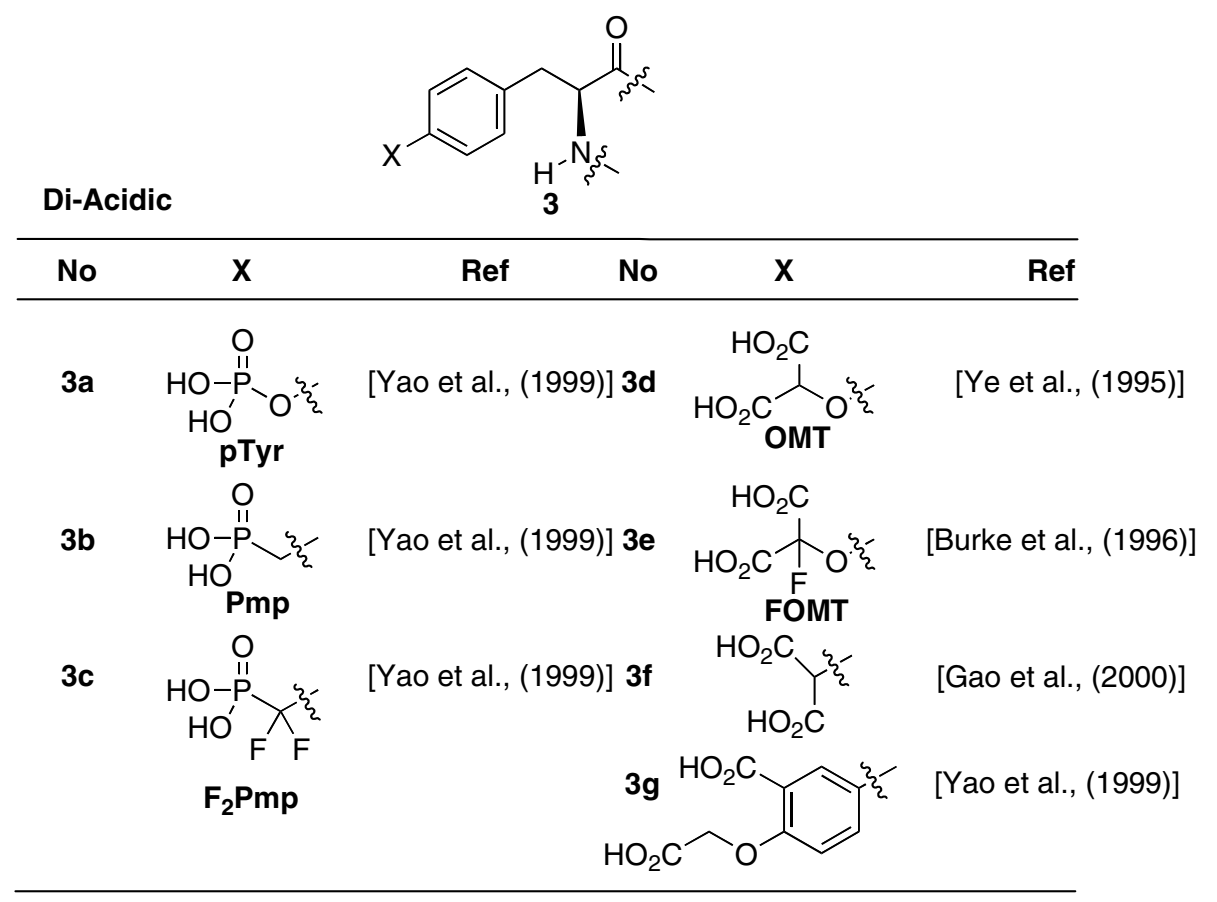

Fig. 4. Structures of various di-acidic pTyr mimetics.

transport problems. Several mono-acidic pTyr mimetics have also been examined in Grb2 $\mathrm{SH} 2$ domain-directed ligands. These include $O$-carboxymethyltyrosine (Cmt, 4a, Fig. 5) (Burke et al., 1999), $O$-difluorocarboxymethyltyrosine $\left(\mathrm{F}_{2} \mathrm{Cmt}, \mathbf{4 b}\right)$ (Fretz et al., 2000), carboxymethylphenylalanine (Cmf, 4c) (Burke et al., 1999) and difluorocarboxymethylphenylalanine (4d) (Burke et al., 1999). Monoacidic phosphinate-based pTyr mimetics 4e-4g have been reported by Furet et al. some of which include benzylic moieties designed to undergo $\pi$-stacking with the $\operatorname{Arg} \beta$ B5 residue (Furet et al., 2000).

\section{MODIFICATIONS TO THE pTyr +1 POSITION}

Exploiting X-ray crystallographic data of Grb2 SH2 domain complexed with a peptide ligand showing that the $\mathrm{pTyr}+1$ residue adapts a $3_{10}$ helical structure (Rahuel et al., 1996), Garcia-Echeverria et al. substituted the pTyr +1 residue of the peptide Ac-pTyr-Val-Asn-amide (5b, Fig. 6) with a series of bend-inducing cycloalkyl amino acids (Garcia-Echeverria et al., 1999). The intent was to promote a local $3_{10}$ helical structure and to afford van der Waals interactions with the side chains of Phe $\beta \mathrm{D} 5$ and Gln $\beta$ D3. Starting with a 3-membered ring $\left(\mathrm{Ac}_{3} \mathrm{c}, \mathbf{5 c}\right)$, binding affinity increased progressively with ring size, reaching a maximum with 1-aminocyclohexane carboxylic acid $\left(\mathrm{Ac}_{6} \mathrm{c}, \mathbf{5 f}\right)$ (Fig. 6). Binding affinity fell off with the larger, 7-membered ring $\left(\mathrm{Ac}_{7} \mathrm{c}, \mathbf{5 g}\right)$.

Garbay and co-workers showed that replacement of the $\mathrm{Ac}_{6} \mathrm{c}$ residue in (3-amino)Z-pTyr-Ac $\mathrm{c}_{6} \mathrm{c}-\mathrm{Asn}$ amide with an $\alpha$-methyl pTyr residue (6a, Fig. 7) resulted in approximately 10 -fold enhancement of Grb2 SH2 domain-binding affinity (Liu et al., 1999, 2004). An X-ray crystal structure of $\mathbf{6 a}$ complexed to the Grb2 SH2 domain showed that key ionic interactions of the $\alpha$-methyl pTyr phosphoryl group with the Arg BG4 guanidinium side chain (identified in Fig. 1) contributed to this effect (Nioche et al., 2002). The $\alpha$-methyl pTyr phosphoryl group was replaced with several hydrolytically-stable mimetics. Although the phosphonomethyl (6b), and difluorophosphonomethyl (6c) containing analogues exhibited markedly less affinity than the parent $\alpha$-methyl pTyr, the $\alpha$-methyl phosphonophenylalanyl residue (6d) was nearly equipotent. Mono-acidic carboxy-based analogues $6 \mathbf{6}$ and $\mathbf{6 f}$ were less potent.

\section{pTyr + 2 Asn REPLACEMENTS}

Studies have shown that Grb2 SH2 domainbinding peptides have a strong preference for an Asn residue at the $\mathrm{pTyr}+2$ position (Songyang et al., 
<smiles>[X]c1ccc(CC(NC(C)C)C(C)=O)cc1</smiles>

4

Mono-Acidic

\begin{tabular}{llllll} 
No & $X$ & Ref & No & $X$ & Ref \\
\hline
\end{tabular}

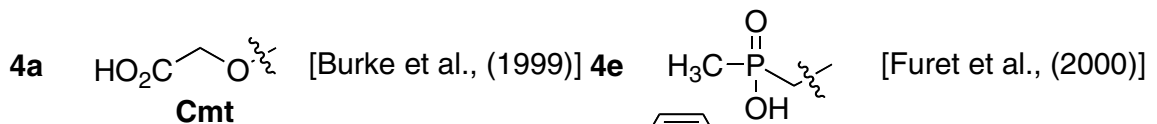

4b

$\mathrm{HO}_{2} \mathrm{C} \mathrm{X}_{\mathrm{O}^{2} \xi_{2}}^{\mathrm{F}}$ [Fretz et al.,(2000)]

$\mathrm{F}_{2} \mathrm{Cmt}$

$4 f$

4c

$\mathrm{HO}_{2} \mathrm{C} \backslash \xi \xi \quad$ [Burke et al., (1999)]

Cmf

4d

$\mathrm{HO}_{\mathrm{F}}^{\mathrm{HO}_{\mathrm{F}}} \underset{\mathrm{K}}{\mathrm{\xi}_{2}}$ [Burke et al., (1999)] $\mathbf{4 g}$

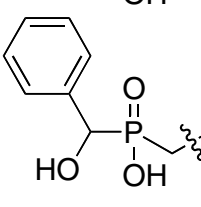

[Furet et al.,(2000)]

Fig. 5. Structures of various mono-acidic pTyr mimetics.<smiles>[X][C@H](NC(=O)N[C@@H](CC(N)=O)C(N)=O)C(=O)N[C@@H](Cc1ccc(P(=O)(O)O)cc1)C(C)=O</smiles>

\begin{tabular}{|c|c|c|c|c|c|}
\hline No & $x$ & $\mathrm{IC}_{50}(\mu \mathrm{M})$ & No & $x$ & $\mathrm{IC}_{50}(\mu \mathrm{M})$ \\
\hline $5 a$ & & 67.0 & $5 e$ & & 7.9 \\
\hline $5 b$ & & 4.3 & $5 f$ & & 0.21 \\
\hline $5 c$ & $\begin{array}{l}y_{2}^{2} \\
\mathrm{Ac}_{3}\end{array}$ & 72.5 & $5 g$ & $A c_{7}$ & 1.11 \\
\hline $5 d$ & $\begin{array}{l}-25 \\
\mathrm{Ac}_{4} \mathrm{C}\end{array}$ & 18.2 & & & \\
\hline
\end{tabular}

Fig. 6. Systematic modifications to the pTyr +1 residue as reported in (Garcia-Echeverria et al., 1999). 
<smiles>[X]c1ccc(C[C@@](C)(NC(=O)[C@H](Cc2ccc(OP(=O)(O)O)cc2)NC(=O)OCc2cccc(N)c2)NC(=O)[C@H](CC(N)=O)C(N)=O)cc1</smiles>

\begin{tabular}{|c|c|c|c|c|c|}
\hline No. & $x$ & $\mathrm{IC}_{50}(\mathrm{nM})$ & No. & $x$ & $\mathrm{IC}_{50}(\mathrm{nM})$ \\
\hline $6 a$ & & 11 & 6d & & 14 \\
\hline $6 b$ & & $265^{1}$ & $6 e$ & $\xi^{-s} \cdot \mathrm{CO}$ & 153 \\
\hline $6 c$ & & 64 & $6 f$ & & 198 \\
\hline
\end{tabular}

${ }^{1}$ Mixture of $\mathrm{D} / \mathrm{L}$ epimers at the $\mathrm{pY}+1$ residue.

Fig. 7. Examination of bend-inducing pTyr mimetics at the $i+1$ position as reported in (Liu et al., 1999).

1994; Kessels et al., 2002). The structural basis for this preference became evident from X-ray studies that showed the Asn residue to be lying at the $i+2$ position of a type-I $\beta$-turn with its side chain carboxamide moiety held in place by three hydrogen bonds arising from the Lys $\beta$ D6 and Leu $\beta \mathrm{E} 4$ residues (Rahuel et al., 1996). Using the high affinity peptide (3-amino)Z-pTyr-Ac 6 c-Asn-amide (7a, Fig. 8), Furet et al. examined Asn replacements consisting of cyclic $\beta$-amino acids of differing ring size that were intended to maintain the network of hydrogen bonds found with the parent Asn side chain carboxamide (Furet et al., 1999). Replacement with a $(1 S, 2 R)$-2-amino-cyclohex-3-ene carboxylic acid (Achec) residue (7c) maintained binding affinity nearly equal to the parent Asn residue. Replacement with the enantiomeric $(1 R, 2 S)$-Achec residue $(\mathbf{7 b})$ resulted in greater than 1000 -fold less affinity, presumably through steric interactions with the Trp EF1 residue.

\section{pTyr + 3 REPLACEMENTS}

X-ray crystal structures of ligand-complexed $\mathrm{Grb} 2 \mathrm{SH} 2$ domain reveal the presence of a lipophilic region formed by the side chains of the Lys $\beta \mathrm{D} 6$ and Leu $\beta \mathrm{D} 1$ and bounded by Phe $\beta \mathrm{E} 3$, which is situated proximal to the binding region of the $\mathrm{pTyr}+3$ residue (Rahuel et al., 1996; Furet et al., 1998). Through a systematic study, Furet et al. showed that replacement of the pTyr +3 residue with a 3-naphthalen-propyl amide significantly enhanced binding affinity, particularly when used in combination with a pTyr +1 Ac$_{6}$ c residue (8a, Fig. 9) (Furet et al., 1998). Subsequently using a convergent synthetic approach, Schoepfer et al. prepared a series of hydroxy and methoxy-substituted congeners, including $\mathbf{8 b}$ and $\mathbf{8 c}$, that exhibited higher binding affinity (Schoepfer et al., 2001). In further work, Schoepfer replaced the naphthyl ring with a variety of substituted indolyl rings (Schoepfer et al., 1999). Depending on the site 
<smiles>[Z]COC(=O)N[C@H](Cc1ccc(OP(=O)(O)O)cc1)C(=O)NC1(C(=O)P)CCCCC1</smiles>

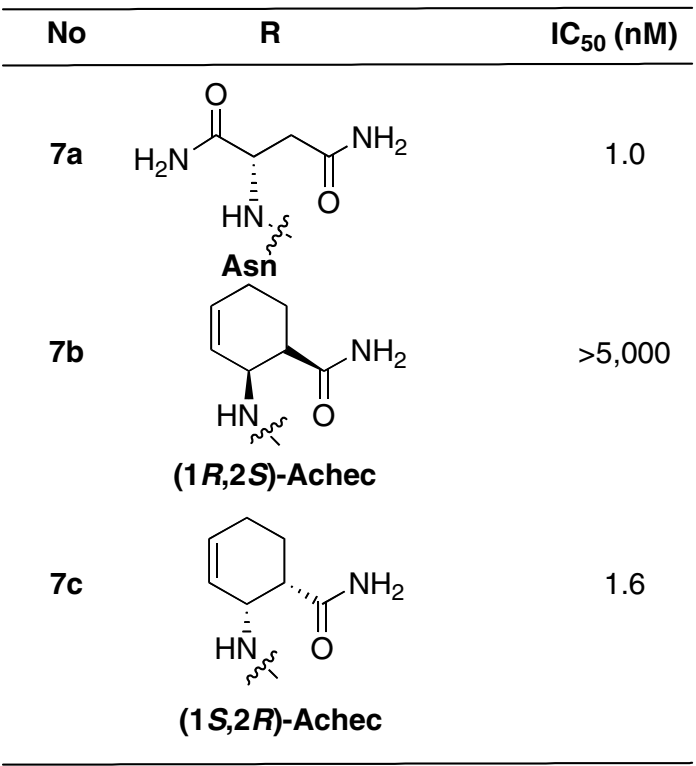

Fig. 8. Replacement of the pTyr +2 Asn residue as reported in (Furet et al., 1999).

of propyl amide attachment (for example, 8d as compared to 8e) and substituents appended to the indolyl ring, highly potent binding inhibitors could be obtained. These included compounds such as $\mathbf{8 f}$ that were the first analogues reported to exhibit subnanomolar Grb2 SH2 domain-binding affinities. Higher affinity of indolyl vs. naphthyl-containing compounds was attributed to enhanced $\mathrm{CH} / \pi$ interactions of the former with segments of the Lys $\beta$ D6 and Leu $\beta \mathrm{D} 1$ side chains that formed the lipophilic binding surface.

\section{USE OF CONFORMATIONAL CONSTRAINT}

The net Grb2 SH2 domain-binding affinity of flexible analogues is adversely affected by free energy terms derived from the ordering of ligands in solution to conformations needed for binding. Theoretically, affinity enhancement can be achieved through reduction of these entropy penalties by induction of conformational constraint. This has already been shown above by the beneficial binding effects of $\mathrm{pTyr}+1$ bend-inducing residues such as $\mathrm{Ac}_{6} \mathrm{c}(\mathbf{5 f})$. In the following, further examples will be provided where induction of conformational constraint has been applied to the design of Grb2 SH2 domainbinding ligands. The approaches presented can be categorized generally into local conformational constraint and global conformational constraint.

\section{Monomeric Constrained pTyr Mimetics}

Introduction of ring structures into amino acid analogues can be used to achieve conformational constraint. The bicyclic indanyl-containing analogue 10 and the tricyclic methanobenzazocino compound 11 were designed to contain within their frameworks, pTyr residues having $\chi_{2}$ (for 10) and $\phi, \chi_{1}$ and $\chi_{2}$ (for 11) angles constrained to values approximating those needed for binding as determined by X-ray crystal structures of SH2 domain-bound pTyr residues (9) (Fig. 10) (Burke et al., 1995). Although this approach is conceptually appealing, little if any affinity enhancement is achieved, and the binding constants of pTyr itself and the constrained analogues $\mathbf{1 0}$ and $\mathbf{1 1}$ are in the millimolar range (Burke et al., 1995; Wang et al., 2003).

\section{Constrained pTyr Mimetics Within Peptide Platforms}

Conformationally constrained pTyr mimetics have also been examined within peptide platforms. Analogues 12 (Plake et al., 2003) and 13 (Liu et al., 2002) (Fig. 11) utilized cyclopropyl and cyclohexyl rings, respectively, to lock both $\phi$ and $\chi$ angles. While peptide 12 maintained a binding on-rate similar to the parent pTyr-containing congener, analogue 13 exhibited a greater than two orders of magnitude loss of binding affinity relative to the un-constrained parent. A similarly large loss of binding affinity was observed for compound 14, which made an alternate use of a cyclohexyl moiety to constrain $\chi_{1}$ and $\chi_{2}$ angles (Oishi et al., 2004). To date, local conformational constraint of the pTyr mimicking residue has not proven to be a useful approach toward affinity enhancement of Grb2 SH2 domain-binding ligands. 
<smiles>[R]CCCNC(=O)[C@H](CC(N)=O)NC(=O)C1(NC(=O)[C@H](Cc2ccc(P(=O)(O)O)cc2)NC(C)=O)CCCCC1</smiles>

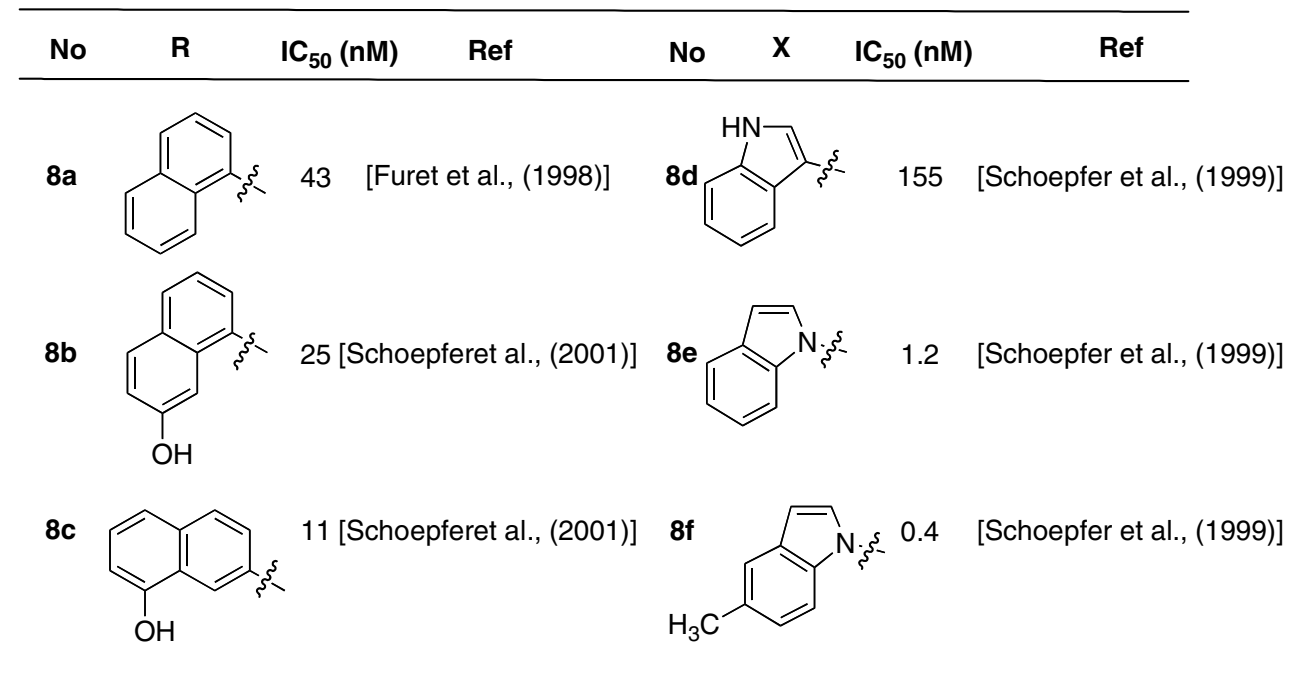

Fig. 9. Modifications to the C-terminal $\mathrm{pTyr}+3$ position.

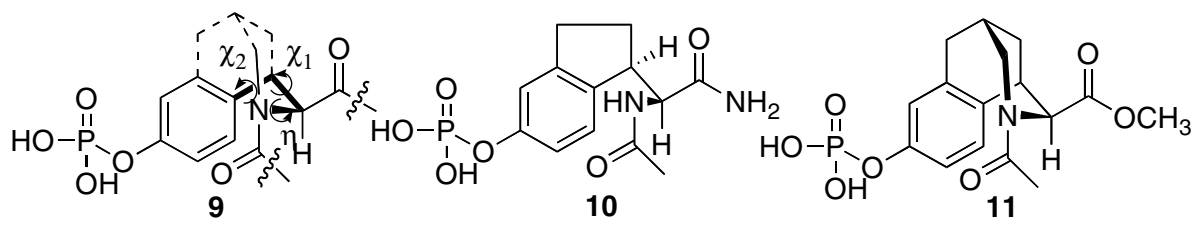

Fig. 10. Structures of conformationally-constrained monomeric pTyr mimetics.

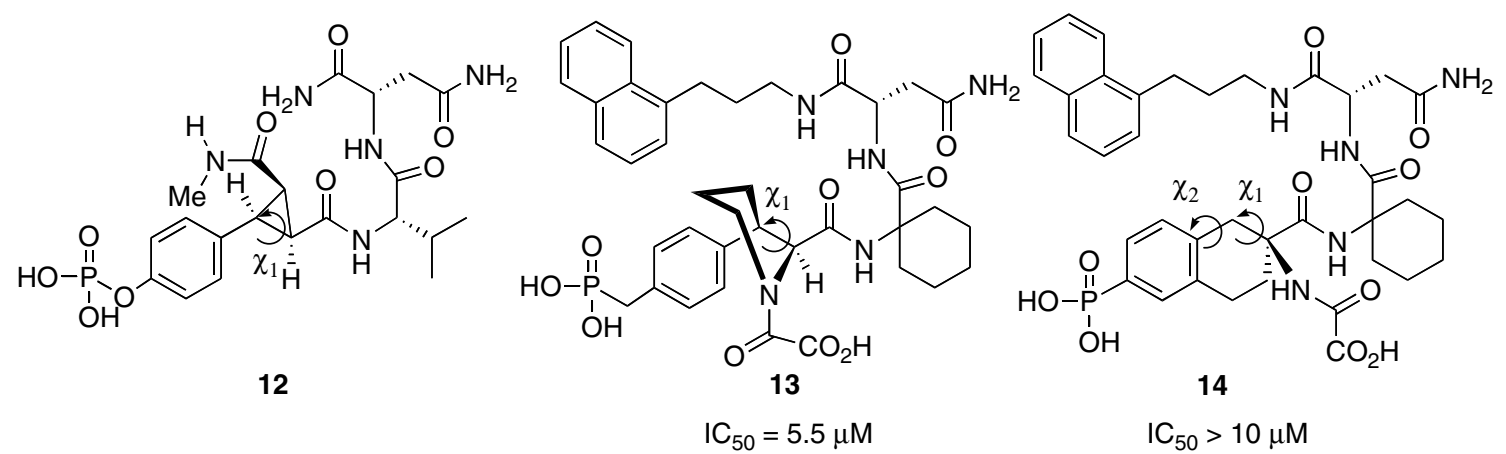

Fig. 11. Constrained pTyr mimetics within peptide platforms. 


\section{Global Conformational Constraint Through Head-to-Tail Cyclization pTyr-Containing Peptides}

While local conformational constraint of pTyr mimetics has not proven beneficial to date, the preferential binding of Grb2 $\mathrm{SH} 2$ domain peptides in $\beta$-bend conformations has made induction of global conformational constraint through macrocyclization an important field of investigation. Ettmeyer et al. examined a series of cyclic peptides (15) based on the sequence pTyr-Val-Asn-Val-Pro) (Fig. 12) (Ettmayer et al., 1999). These included analogues 15a $\left(\mathrm{IC}_{50}=\right.$ $0.06 \mu \mathrm{M})$ and $\mathbf{1 5 b}\left(\mathrm{IC}_{50}=0.07 \mu \mathrm{M}\right)$, which exhibited approximately 10 -fold higher affinity than the open chain congeners such as $\mathbf{1 5 c}\left(\mathrm{IC}_{50}=1.63 \mu \mathrm{M}\right)$. This is in contrast to the findings of Dekker et al. that ring closing metathesis (RCM) of open-chain 16 $\left(K_{\mathrm{d}}=0.44 \mu \mathrm{M}\right)$ to unsaturated $17\left(K_{\mathrm{d}}=0.60 \mu \mathrm{M}\right)$ and saturated $18\left(K_{\mathrm{d}}=0.48 \mu \mathrm{M}\right)$ failed to enhance binding affinity (Fig. 13) (Dekker et al., 2003).

\section{Cyclic Peptides Based a Non-pTyr-Containing Phage Library Lead}

High affinity binding to the $\mathrm{SH} 2$ domains normally requires a $\mathrm{pTyr}$ or $\mathrm{p}$ Tyr-mimicking residue that can form ionic interactions with positively-charged residues within the pTyr binding pocket, particularly with the Arg $\beta$ B5 residue (Bradshaw et al., 1999). In this light, a noteworthy body of work has appeared on several Grb2 SH2 domain-binding peptides whose designs are predicated on a non-pTyr-containing disulfide-cyclized phage library-derived lead termed 'G1' (19a, $\left.\mathrm{IC}_{50}=10-25 \mu \mathrm{M}\right)$ and its thioether homologue 'G1TE' (19b, IC $50=20 \mu \mathrm{M}$ ) (Fig. 14) (Oligino et al., 1997). Through the preparation of an extensive series of analogues, binding affinity was enhanced to low nanomolar values (Li et al., 2003a). The use of a Tyr instead of a pTyr in the original G1TE (19b) with maintenance of binding affinity, was shown to be due to the compensatory action of a Glu residue in the Tyr-2 position that supplied anionic interactions with the critical protein Arg $\beta$ B5 residue (Li et al., 2003c). Further modifications including addition of a second carboxyl group to the Glu residue, replacement of the Tyr residue with a 3-amino-Tyr residue and conversion of the ring-closing thioether to an $(R)$-sulfoxide, lead to cyclic peptide $\mathbf{2 0}$, which exhibited an $\mathrm{IC}_{50}$ value of $50 \mathrm{nM}$ (Song et al., 2004). High affinity variants of these peptides have been prepared that utilize pTyr mimetics, such as $\mathbf{2 1}, \mathrm{IC}_{50}=2.4 \mathrm{nM}$.

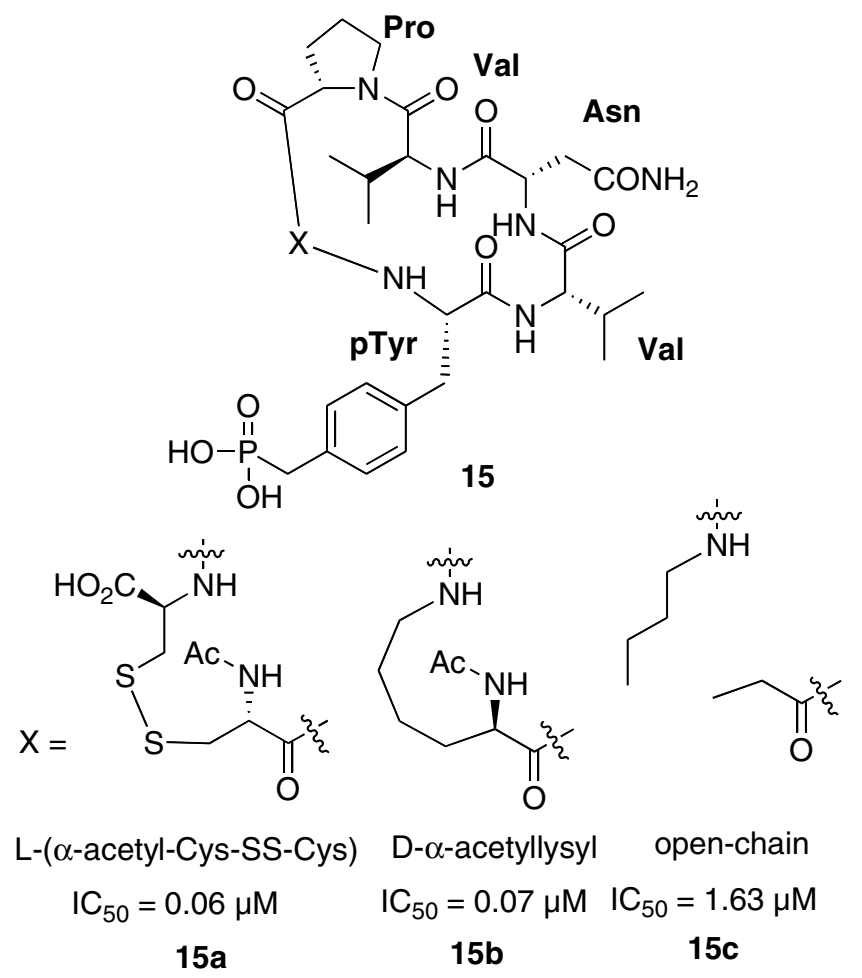

Fig. 12. Structures of cyclic peptides reported in (Ettmayer et al., 1999). 


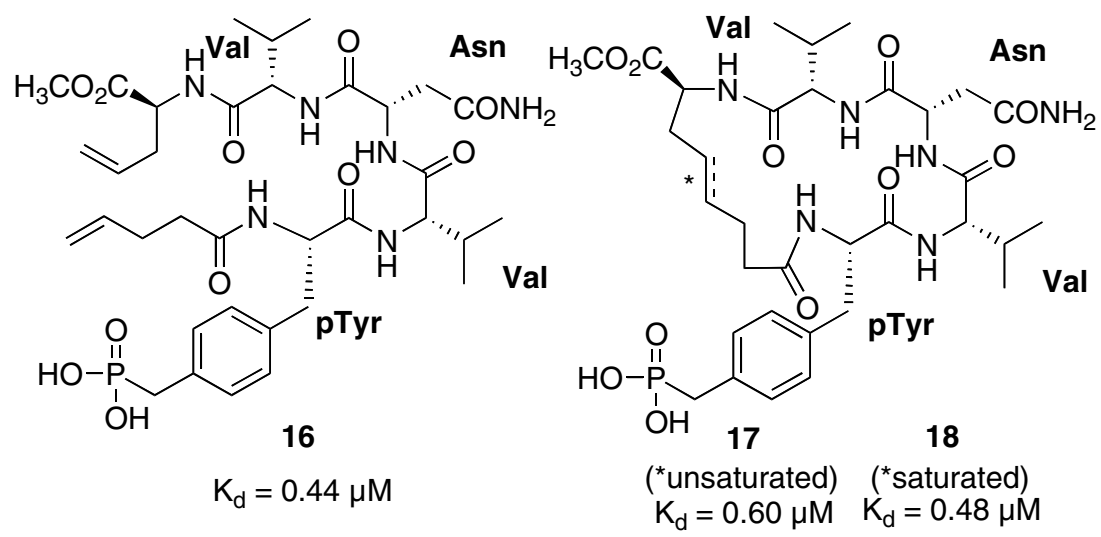

Fig. 13. RCM-derived peptides described in (Dekker et al., 2003).

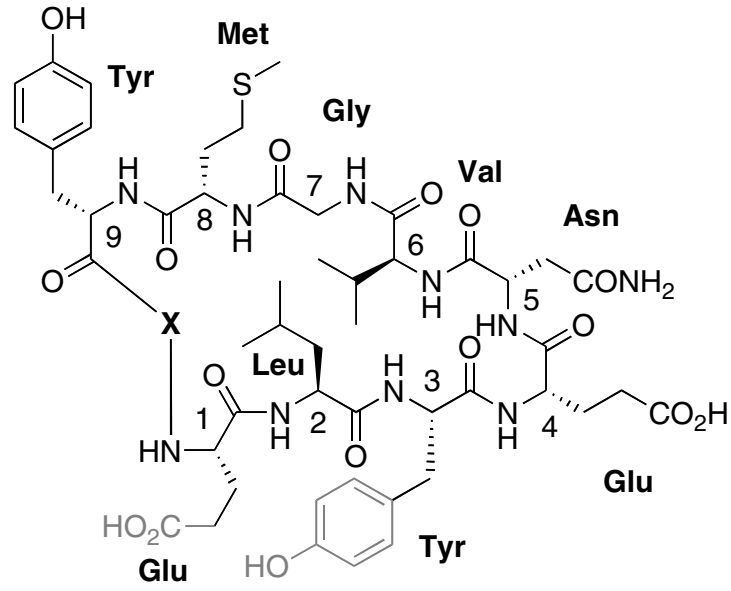

19

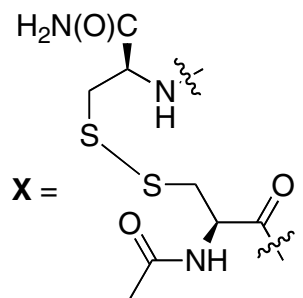

$19 a$

"G1"

$\mathrm{IC}_{50}=10-25 \mu \mathrm{M}$

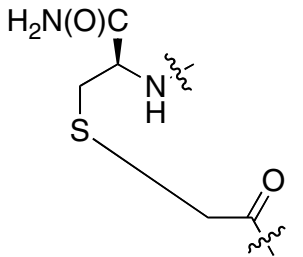

$19 b$

"G1TE"

$\mathrm{IC}_{50}=20 \mu \mathrm{M}$

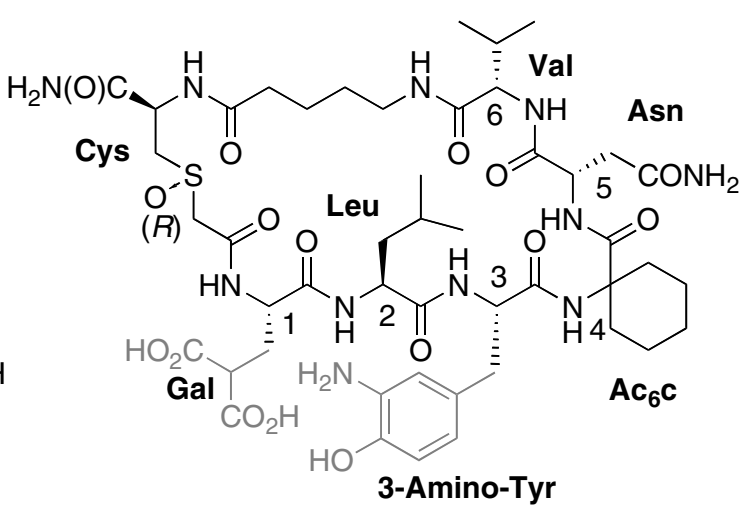

20

$\mathrm{IC}_{50}=50 \mathrm{nM}$

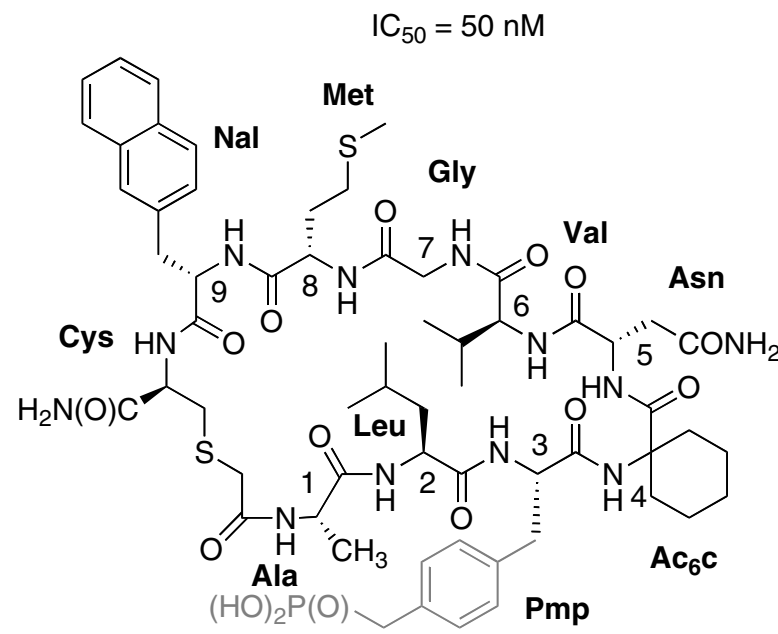

21

$\mathrm{IC}_{50}=2.4 \mathrm{nM}$

Fig. 14. Structures of Grb2 SH2 domain-binding cyclic peptides based on the non-pTyr-containing phage library-derived lead 19a. Grey indicates phenyl phosphoryl-mimicking functionality. 


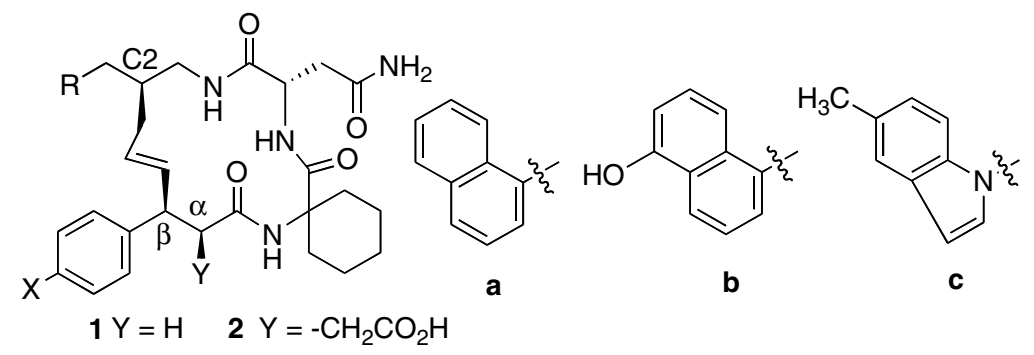

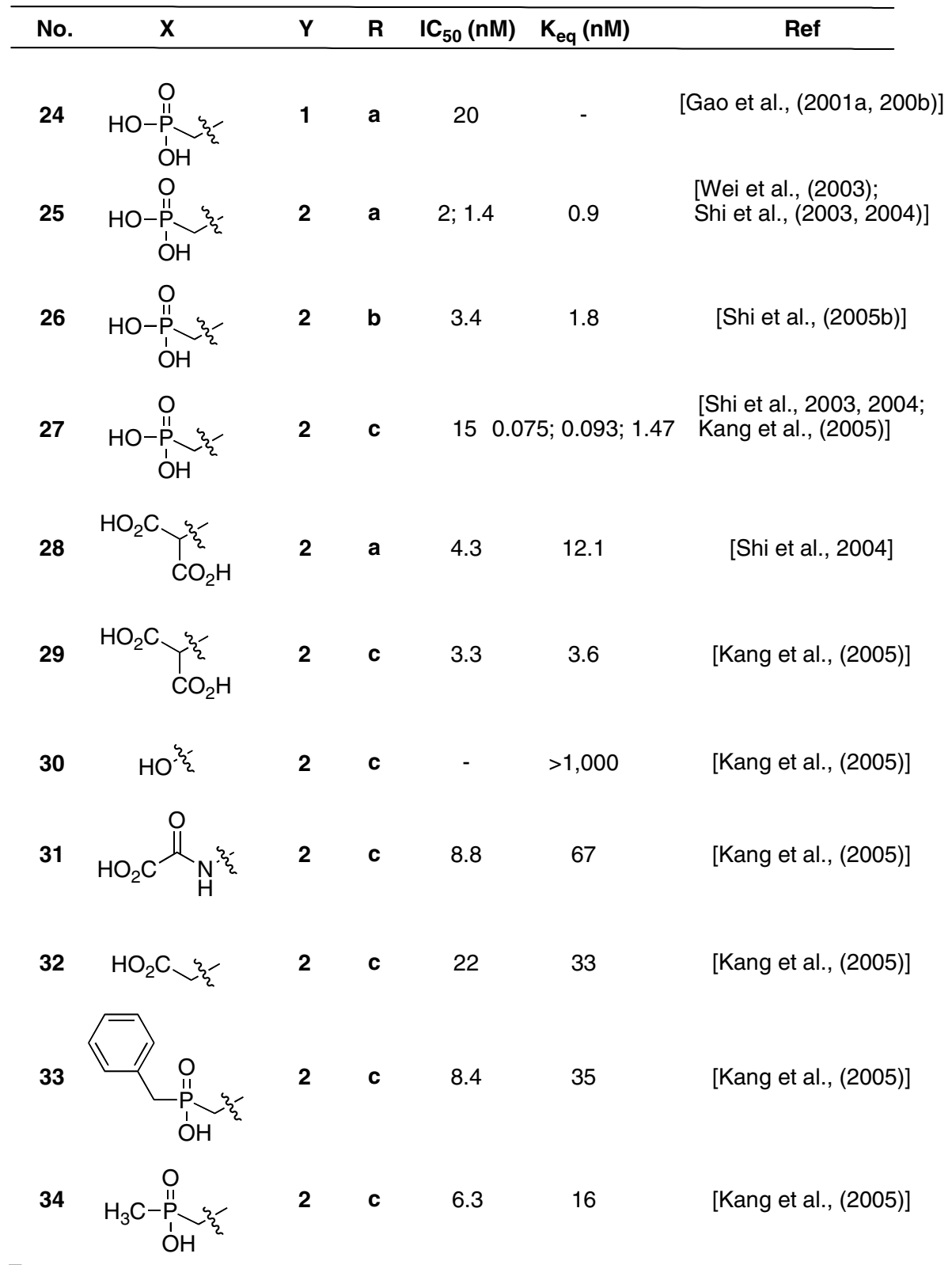

Fig. 15. Macrocycles formed by RCM reactions originating at the $\mathrm{pTyr}$ mimetic $\beta$-position. 


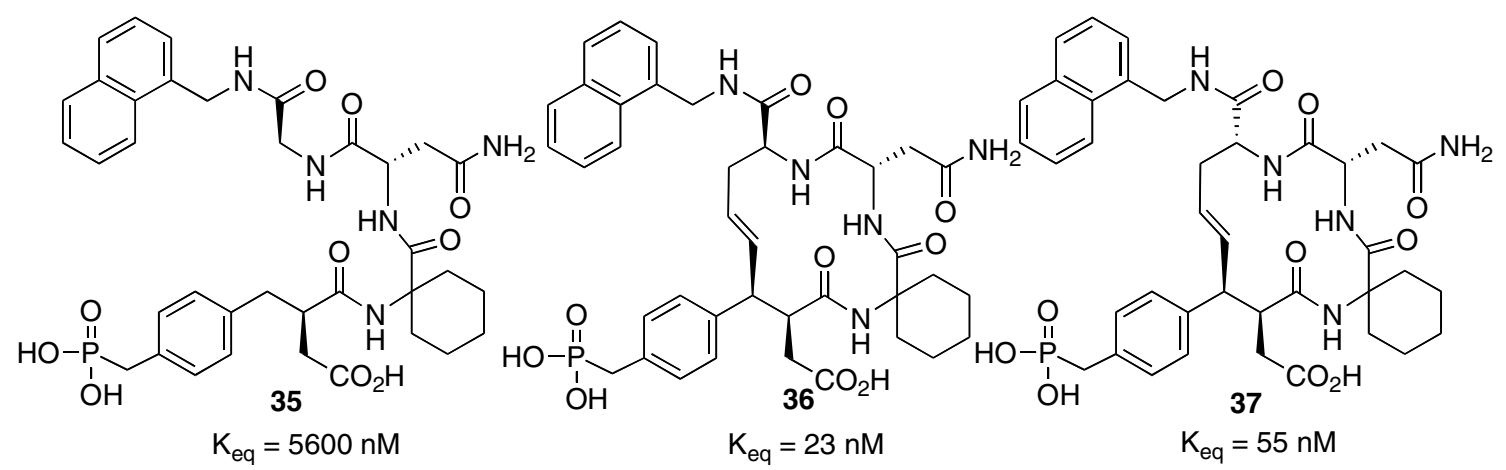

Fig. 16. $\mathrm{RCM}$ macrocyclization at the $\mathrm{pTyr}$ mimetic $\beta$-position using $\mathrm{C}$-terminal allylglycine residues.<smiles>CC(=O)N[C@H](Cc1ccc(OP(=O)(O)O)cc1)C(=O)N[C@H](C(=O)N[C@@H](CC(N)=O)C(N)=O)C(C)C</smiles>

Fig. 17. Non-peptidic compounds 38 and 39 based on tripeptide 38.

However, these require that the compensatory acidic residue at the Tyr-2 position also be replaced by a non-acidic residue, such as Ala (Li et al., 2003b).

\section{Macrocycles Derived From Ring Closure at the pTyr Mimetic $\beta$-Methylene}

Molecular modeling studies of open-chain peptides such as 8a (Fig. 9) bound to the Grb2 $\mathrm{SH} 2$ domain indicated that the $\beta$-methylene of the $\mathrm{N}$-terminal $\mathrm{pTyr}$ mimicking residue was in close proximity to $\mathrm{C} 2$ of the C-terminal naphthylpropylamido group (Gao et al., 2001a). Ring closure from these two positions using RCM chemistries yielded the new family of macrocycles shown in Fig. 15 (Gao et al., 2001b; Wei et al., 2003). Macrocycle 24, which lacked any functionality at the $\mathrm{pTyr}$ mimetic $\alpha$-position, exhibited an $\mathrm{IC}_{50}$ value of $20 \mathrm{nM}$ in extracellular ELISA binding assays, yet was unable to block the intracellular association of Grb2 with cytoplasmic erbB-2 PTK in whole cells following extracellular administration (Gao et al., 2001a). However, introduction of an $\alpha$-carboxymethyl group onto $\mathbf{2 4}$ to yield $\mathbf{2 5}$ not only resulted in an order of magnitude enhancement of binding affinity in extracellular assays, but also imparted the ability to block the association of Grb2 with cytoplasmic erbB-2 PTK in whole cells following extracellular administration (Wei et al., 2003). By analogy to SAR studies conducted on open-chain peptides (Fig. 9), the naphthyl ring of $\mathbf{2 5}$ was replaced with a 5-hydroxynaphthyl group (compound 26) (Shi et al., 2005b) or a 5methylindolyl group (compound 27) (Shi et al., 2003, 2004); Kang et al., 2005). This resulted in potency enhancement, such that $\mathbf{2 7}$ was able to block the association of Grb2 with cytoplasmic erbB-2 PTK in whole cells at low nanomolar concentrations when given in extracellular medium. Interestingly, the absolute configuration at the $\mathrm{C} 2$ ring juncture has little effect on binding affinity (Shi et al., 2005a). A variety of phosphoryl-mimicking moities were also examined (compounds 28-34), including several mono-acidic groups that provided low nanomolar binding affinities (Kang et al., 2005).

A modification of this approach has recently been reported, whereby allylglycine residues were used to form the C-terminal ring-closing segments (Oishi 
<smiles>[R]C(=O)N[C@@H](Cc1ccc([X])cc1)C(=O)N[Y](=O)N[C@@H](CC(N)=O)C(=O)NCCCc1c([R])ccc2ccccc12</smiles>

No

Fig. 18. Structures of Grb2 SH2 domain-binding inhibitors that have been examined in whole cell systems.

et al., 2005). Significant enhancements in Grb2 SH2 domain-binding affinity were observed for ring-closed products (36 and 37 ) as compared to the open-chain parent (35) (Fig. 16). Similar to above, the absolute configuration at the $\mathrm{C}$-terminal ring junction had little effect on binding affinity.

\section{NON-PEPTIDIC COMPOUNDS}

Starting from the minimal peptide Ac-pTyr-ValAsn-amide $\left(38, \mathrm{IC}_{50}=4.32 \mu \mathrm{M}\right)$, Schoepfer et al. replaced the Val-Asn portion with a (3-aminomethylphenyl) urea to form tripeptide-mimicking compound $39\left(\mathrm{IC}_{50}=6.19 \mu \mathrm{M}\right)$, which exhibited similar Grb2 SH2 domain-binding affinity (Fig. 17) (Schoepfer et al., 1998). Caravatti et al. went further and replaced all amino acid components to yield the tri-aromatic analogue $\mathbf{4 0}\left(\mathrm{IC}_{50}=25.9 \mu \mathrm{M}\right)$, which still retained low micromolar binding affinity (Caravatti et al., 1999).

\section{CELLULAR STUDIES}

The highly polar nature of pTyr and pTyr mimicking residues limits cell membrane transport of many Grb2 SH2 domain-binding antagonists. However, whole cell studies conducted following prodrug derivatization of the inhibitor phosphoryl or phosphonic acid moieties have been reported. Work done by Gay et al. using CGP78850 (compound 41, Fig. 18), a selective Grb2 SH2 domain-binding inhibitor having a mixed phosphoramidite/phenyl ester - protected phosphonic acid group, showed that this compound could block the association of Grb2 with activated epidermal growth factor receptor (EGFR) in living cells and inhibit the growth of cells driven by PTK signaling through Ras (Gay et al., 1999a). Further studies showed that CGP78850 could inhibit hepatocyte growth factor (HGF)-induced cell motility (Gay et al., 1999b). Using a monobenzyl phosphoryl protection protocol Garbay and co-workers showed that compound $\mathbf{4 2}$ could 
block soft agar colony formation of HER2 transfected cells with a sub-micromolar $\mathrm{IC}_{50}$ value (Liu et al., 2004). In work that did not rely on prodrug protection, Bottaro and co-workers showed that compound 43, which employs a malonyl-based phosphoryl mimetic, was able to block HGF-induced cell motility, matrix invasion and morphogenesis with $\mathrm{IC}_{50}$ values of $300 \mathrm{nM}$ or less (Atabey et al., 2001; Soriano et al., 2004).

\section{CONCLUSIONS}

This review has presented an overview of Grb2 $\mathrm{SH} 2$ domain-directed inhibitor development. Although several high affinity inhibitors have been reported, including agents that exhibit potent effects in cellular systems, studies in whole animal cancer models have yet to appear. This may be due in part to the success of PTK inhibitors that has muted enthusiasm within the pharmaceutical industry for $\mathrm{SH} 2$ domain-directed inhibitors. It may also reflect scale up and bioavailability issues presented by some of the most promising inhibitors. Only time will tell whether these latter issues will be overcome to a sufficient extent to allow clinical trials of this class of agents.

\section{REFERENCES}

Atabey, N., Gao, Y., Yao, Z. -J., Breckenridge, D., Soon, L., Soriano, J. V., Burke, T. R. Jr. and Bottaro, D. P.: 2001, J. Biol. Chem. 276, 14308-14314.

Blume-Jensen, P. and Hunter, T.: 2001, Nature 411, 355-365.

Bradshaw, J. M., Mitaxov, V. and Waksman, G.: 1999, J. Mol. Biol. 293, 971-985.

Burke, T. R. and Lee, K.: 2003, Acc. Chem. Res. 36, 426-433.

Burke, T. R. Jr., Barchi, J. J., George, C., Wolf, G., Shoelson, S. E. and Yan, X.: 1995, J. Med. Chem. 38, 1386-1396.

Burke, T. R. Jr., Luo, J., Yao, Z. -J., Gao, Y., Zhao, H., Milne, G. W. A., Guo, R., Voigt, J. H., King, C. R. and Yang, D.: 1999, Bioorg. Med. Chem. Lett. 9, 347-352.

Burke, T. R. Jr., Yao, Z. J., Gao, Y., Wu, J. X., Zhu, X., Luo, J. H., Guo, R. and Yang, D.: 2001a, Bioorg. Med. Chem. 9, 1439-1445.

Burke, T. R. Jr., Yao, Z. -J., Liu, D. -G., Voigt, J. and Gao, Y.: 2001 b, Biopolymers 60, 32-44.

Caravatti, G., Rahuel, J., Gay, B. and Furet, P.: 1999, Bioorg. Med. Chem. Lett. 9, 1973-1978.

Daly, R. J., Binder, M. D. and Sutherland, R. L.: 1994, Oncogene 9, 2723-2727.

Dekker, F. J., de Mol, N. J., Fischer, M. J. E., Kemmink, J. and Liskamp, R. M. J.: 2003, Org. Biomol. Chem. 1, 3297-3303.

Eck, M. J., Shoelson, S. E. and Harrison, S. C.: 1993, Nature 362, $87-91$.
Ettmayer, P., France, D., Gounarides, J., Jarosinski, M., Martin, M.-S., Rondeau, J.-M., Sabio, M., Topiol, S., Weidmann, B., Zurini, M. and Bair, K. W.: 1999, J. Med. Chem. 42, 971980.

Fretz, H., Furet, P., Garcia-Echeverria, C., Rahuel, J. and Schoepfer, J.: 2000, Curr. Pharm. Design 6, 1777-1796.

Furet, P., Gay, B., Garcia-Echeverria, C., Rahuel, J., Fretz, H., Schoepfer, J. and Caravatti, G.: 1997, J. Med. Chem. 40, 3551-3556.

Furet, P., Gay, B., Caravatti, G., Garcia-Echeverria, C., Rahuel, J., Schoepfer, J. and Fretz, H.: 1998, J. Med. Chem. 41, 34423449.

Furet, P., Garcia-Echeverria, C., Gay, B., Schoepfer, J., Zeller, M. and Rahuel, J.: 1999, J. Med. Chem. 42, 2358-2363.

Furet, P., Caravatti, G., Denholm, A. A., Faessler, A., Fretz, H., Garcia-Echeverria, C., Gay, B., Irving, E., Press, N. J., Rahuel, J., Schoepfer, J. and Walker, C. V.: 2000, Bioorg. Med. Chem. Lett. 10, 2337-2341.

Gao, Y., Luo, J., Yao, Z. -J., Guo, R., Zou, H., Kelley, J., Voigt, J. H., Yang, D. and Burke, T. R. Jr.: 2000, J. Med. Chem. 43, 911-920.

Gao, Y., Voigt, J., Wu, J. X., Yang, D. and Burke, T. R. Jr.: 2001a, Bioorg. Med. Chem. Lett. 11, 1889-1892.

Gao, Y., Wei, C. -Q. and Burke, T. R. Jr.: 2001b, Org. Lett. 3, $1617-1620$.

Garcia-Echeverria, C.: 2001, Curr. Med. Chem. 8, 1589-1604.

Garcia-Echeverria, C., Gay, B., Rahuel, J. and Furet, P.: 1999, Bioorg. Med. Chem. Lett. 9, 2915-2920.

Gay, B., Suarez, S., Caravatti, G., Furet, P., Meyer, T. and Schoepfer, J.: 1999a, Int. J. Cancer 83, 235-241.

Gay, B., Suarez, S., Weber, C., Rahuel, J., Fabbro, D., Furet, P., Caravatti, G. and Schoepfer, J.: 1999b, J. Biol. Chem. 274, 23311-23315.

Kang, S. -U., Shi, Z. -D., Worthy, K. M., Bindu, L. K., Dharmawardana, P. G., Choyke, S. J., Bottaro, D. P., Fisher, R. J. and Burke, T. R. Jr.: 2005, J. Med. Chem. 48, 3945-3948.

Kessels, H. W. H. G., Ward, A. C. and Schumacher, T. N. M.: 2002, Proc. Natl. Acad. Sci. USA 99, 8524-8529.

Li, P., Zhang, M., Long, Y. -Q., Peach, M. L., Liu, H., Yang, D., Nicklaus, M. and Roller, P. P.: 2003a, Bioorg. Med. Chem. Lett. 13, 2173-2177.

Li, P., Zhang, M., Peach, M. L., Liu, H., Yang, D. and Roller, P. P.: 2003b, Org. Lett. 5, 3095-3098.

Li, P., Zhang, M., Peach, M. L., Zhang, X., Liu, H., Nicklaus, M., Yang, D. and Roller, P. P.: 2003c, Biochem. Biophys. Res. Commun. 307, 1038-1044.

Liu, W. -Q., Vidal, M., Gresh, N., Roques, B. P. and Garbay, C.: 1999, J. Med. Chem. 42, 3737-3741.

Liu, D. -G., Wang, X. -Z., Gao, Y., Li, B., Yang, D. and Burke, T. R.: 2002, Tetrahedron 58, 10423-10428.

Liu, W. -Q., Vidal, M., Olszowy, C., Million, E., Lenoir, C., Dhotel, H. and Garbay, C.: 2004, J. Med. Chem. 47, 12231233.

Lowenstein, E. J., Daly, R. J., Batzer, A. G., Li, W., Margolis, B., Lammers, R., Ullrich, A., Skolnik, E. Y., Bar-Sagi, D. and Schlessinger, J.: 1992, Cell 70, 431-442.

Million, R. P. and Van Etten, R. A.: 2000, Blood 96, 664-670.

Nioche, P., Liu, W. -Q., Broutin, I., Charbonnier, F., Latreille, M. -T., Vidal, M., Roques, B., Garbay, C. and Ducruix, A.: 2002, J. Mol. Biol. 315, 1167-1177. 
Oishi, S., Kang, S. -U., Liu, H., Zhang, M., Yang, D., Deschamps, J. R. and Burke, T. R. Jr.: 2004, Tetrahedron 60, 2971-2977.

Oishi, S., Shi, Z. -D., Worthy, K. M., Bindu, L. K., Fisher, R. J. and Burke, T. R. Jr.: 2005, ChemBioChem. 6, 668-874.

Oligino, L., Lung, F. -D. T., Sastry, L., Bigelow, J., Cao, T., Curran, M., Burke, T. R. Jr., Wang, S., Krag, D., Roller, P. P. and King, C. R.: 1997, J. Biol. Chem. 272, 2904629052.

Plake, H. R., Sundberg, T. B., Woodward, A. R. and Martin, S. F.: 2003, Tetrahedron Lett. 44, 1571-1574.

Rahuel, J., Gay, B., Erdmann, D., Strauss, A., Garcia, E., Furet, P., Caravatti, G., Fretz, H., Schoepfer, J. and Gruetter, M. G.: 1996, Nature Struct. Biol. 3, 586-589.

Rahuel, J., Garcia-Echeverria, C., Furet, P., Strauss, A., Caravatti, G., Fretz, H., Schoepfer, J. and Gay, B.: 1998, J. Mol. Biol. 279, 1013-1022.

Saucier, C., Papavasiliou, V., Palazzo, A., Naujokas, M. A., Kremer, R. and Park, M.: 2002, Oncogene 21, 1800-1811.

Schiering, N., Casale, E., Caccia, P., Giordano, P. and Battistini, C.: 2000, Biochemistry 39, 13376-13382.

Schoepfer, J., Gay, B., Caravatti, G., Garcia-Echeverria, C., Fretz, H., Rahuel, J. and Furet, P.: 1998, Bioorg. Med. Chem. Lett. 8, 2865-2870.

Schoepfer, J., Fretz, H., Gay, B., Furet, P., Garcia-Echeverria, C., End, N. and Caravatti, G.: 1999, Bioorg. Med. Chem. Lett.9, 221-226.

Schoepfer, J., Gay, B., End, N., Muller, E., Scheffel, G., Caravatti, G. and Furet, P.: 2001, Bioorg. Med. Chem. Lett. 11, 12011203.

Shawver, L. K., Slamon, D. and Ullrich, A.: 2002, Cancer Cell 1, $117-123$.

Shi, Z. -D., Lee, K., Liu, H., Zhang, M., Roberts, L. R., Worthy, K. M., Fivash, M. J., Fisher, R. J., Yang, D. and Burke, T. R.: 2003, Biochem. Biophys. Res. Commun. 310, 378-383.
Shi, Z. -D., Lee, K., Wei, C. -Q., Roberts, L. R., Worthy, K. M., Fisher, R. J. and Burke, T. R. Jr.: 2004, J. Med. Chem. 47, 788-791.

Shi, Z. -D., Karki, R. G., Worthy, K. M., Bindu, L. K., Fisher, R. J. and Burke, T. R. Jr.: 2005a, Chem. Biodivers. 2, 447-456.

Shi, Z. -D., Liu, H., Zhang, M., Worthy, K. M., Bindu, L., Yang, D., Fisher, R. J. and Burke, T. R. Jr.: 2005b, Bioorg. Med. Chem. 13, 4200-4208.

Song, Y. -L., Roller, P. P. and Long, Y. -Q.: 2004, Bioor. Med. Chem. Lett. 14, 3205-3208.

Songyang, Z.: 1999, Prog. Biophys. Mol. Biol. 71, 359-372.

Songyang, Z., Shoelson, S. E., Mcglade, J., Olivier, P., Pawson, T., Bustelo, X. R., Barbacid, M., Sabe, H., Hanafusa, H., Yi, T., Ren, R., Baltimore, D., Ratnofsky, S., Feldman, R. A. and Cantley, L. C.: 1994, Mol. Cell. Biol. 14, 2777-2785.

Soriano, J. V., Liu, N., Gao, Y., Yao, Z. -J., Ishibashi, T., Underhill, C., Burke, T. R. Jr. and Bottaro, D. P.: 2004, Mol. Cancer Ther. 3, 1289-1299.

Tari, A. M. and Lopez-Berestein, G.: 2001, Semin. Oncol. 28, 142-147.

Vu, C. B.: 2000, Curr. Med. Chem. 7, 1081-1100.

Waksman, G., Shoelson, S. E., Pant, N., Cowburn, D. and Kuriyan, J.: 1993, Cell 72, 779-790.

Wang, X. -Z., Yao, Z. -J., Liu, H., Zhang, M., Yang, D., George, C. and Burke, T. R. Jr.: 2003, Tetrahedron 59, 6087-6093.

Wei, C. -Q., Gao, Y., Lee, K., Guo, R., Li, B., Zhang, M., Yang, D. and Burke, T. R. Jr.: 2003, J. Med. Chem. 46, 244-254.

Yao, Z. -J., King, C. R., Cao, T., Kelley, J., Milne, G. W. A., Voigt, J. H. and Burke, T. R. Jr.: 1999, J. Med. Chem. 42, 25-35.

Ye, B., Akamatsu, M., Shoelson, S. E., Wolf, G., Giorgetti-Peraldi, S., Yan, X., Roller, P. P. and Burke, T. R. Jr.: 1995, J. Med. Chem. 38, 4270-4275. 